\title{
RELAÇÕES RACIAIS: POR UM PENSAR CRÍTICO SOBRE A BRANQUITUDE
}

\section{RACIAL RELATIONSHIPS: FOR A CRITICAL THINKING ABOUT WHITENESS}

\author{
Maria Auxiliadora de Almeida Arruda ${ }^{1}$ \\ [https://orcid.org/0000-0003-3443-5099] \\ DOI: 10.30612/raido.v15i37.14392
}

\begin{abstract}
RESUMO: O racismo e a discriminaçáo racial săo constitutivos da formaçâo social brasileira. Nesse contexto, este artigo propóe uma discussăo crítica sobre a branquitude, que se refere à forma como os sujeitos brancos se apropriam da categoria raça e do racismo na constituiçấo de suas subjetividades e, ao se apropriarem, acreditam que "ser branco" determina características morais, intelectuais e estéticas dos indivíduos e que os distinguem dos "outros" racializados. Para isso, foram priorizados estudos críticos sobre a branquitude cuja lógica é fazer um deslocamento de estudo dos "outros" racializados para o ponto central da construçăo da ideia de raça, ou seja, para os brancos. Na direçăo de uma educaçâo antirracista propôe-se uma pedagogia crítica da branquitude no sentido de problematizá-la enquanto modelo universal de humanidade, por meio de uma prática dialógica em que os sujeitos e grupos sociais (re)construam a branquitude como uma representaçăo năo fixa e guiada por referenciais que se associam com lutas, relaçóes e práticas democráticas e comprometidas com a humanizaçăo autêntica dos sujeitos.
\end{abstract}

Palavras-chave: Antirracismo; relaçōes étnico-raciais; branquitude; educaçăo; ensino.

ABSTRACT: Racism and racial discrimination are constitutive of brazilian social formation. In this contexto, this article offers a critical discussion on whiteness, which refers to the way in which whites are appropriate for the category race and racism in the constitution of their subjectivities and when appropriate that "being whitw" determines the moral, intellectual and aesthetic characteristics of individuals that differentiate from the racialized "others". To this end, priority was given to critical studies on whiteness whose logic is to shift the study from the racialized "others" to the central point of the construction of the idea of race, that is, for whites. In the direction of na anti-racist Education, a critical pedagogy of whiteness is proposed in order to problematize it as a universal model of humanity, through a dialogical practice in which subjects and social groups (re) build whiteness as a non-fixed representation and guided by references that are associated with struggles, relations and democratic practices and committed to the authentic humanization of subjects.

Keywords: Anti-racism; Ethnic and race relations; whiteness; education; teaching

1 Professora efetiva da área de Pedagogia do Curso de Licenciatura em Ciências Biológicas do Instituto Federal de Mato Grosso - IFMT - Campus Avançado Diamantino. Doutora em Sociologia. Líder do Grupo de Pesquisa: Estudos Críticos da Branquitude - DGP/CNPq. E-mail: maria.almeida@dmt.ifmt.edu.br 


\section{INTRODUÇÃO}

O racismo é um princípio organizador ou uma lógica estruturante de todas as configuraçôes sociais e relaçôes de dominaçâo da modernidade (GROSFOGUEL, 2018). No contexto social e histórico da modernidade, o colonialismo se constituiu como um empreendimento capitalista racista que converteu o que é genuinamente humano em objeto de sua acumulaçáo. O colonialismo representa a negaçâo do conhecimento do outro como sujeito e do direito à diferença, ou seja, o colonizado é uma coisa, um objeto, um năo humano. Pressupóe uma racializaçáo onde o único que é visto como sujeito é o branco, europeu, colonizador. "O branco incita-se a assumir a condiçăo de ser humano" (FANON, 2008, p.27) e essa apropriaçăo do mito do modelo universal de humanidade, acaba legitimando a sua supremacia econômica, política e social em detrimento dos demais grupos sociais (BENTO, 2014).

Com efeito, o racismo contra os grupos sociais racializados como indígenas e negros, por exemplo, coloca-os na condiçâo de inferiorizados, maléficos ao desenvolvimento da naçăo e sujeitos às diversas formas de escravizaçâo. De maneira que, na história do Brasil os povos indígenas foram os primeiros a serem escravizados na montagem dos engenhos de cana-de-açúcar antes da escravizaçâo dos africanos capturados de seu continente original em meados do século XVI (MILANEZ et al, 2019). As consequências desse processo continuam sendo silenciadas pelo falacioso mito da democracia racial, segundo o qual, acredita-se que as relaçóes entre branco e negro, e branco e indígena săo desprovidas de preconceito e discriminaçăo por causa da miscigenaçăo, prevalecendo a ideia de que o preconceito no Brasil é de ordem socioeconômica e náo racial, ou seja, o preconceito náo é baseado na diferença fenotípica.

Na década de 1950, o sociólogo Guerreiro Ramos criticou os estudos das relaçóes de raça no Brasil centrados no negro como tema, como problema feitos por sociológicos e antropólogos adeptos ao biologismo e propôs uma inversăo ao estudar a branquitude como uma patologia social e a normalizaçâo do padrăo branco em nossa sociedade. "No plano ideológico, é dominante ainda a brancura como critério de estética social" (RAMOS, 1995, p.171-172). Para o autor, a minoria dominante de origem europeia usou a força, a violência e um sistema de pseudojustificaçōes de estereótipos ou de processos de domesticaçấo psicológica para afirmar a dogmática da excelência da brancura e da degradaçấo estética da cor negra.

Nesse sentido, o patológico seria a identificaçăo do branco brasileiro com o padráo estético europeu e a permanência desses dogmas após a aboliçăo, quando se produziu situaçôes de absorçăo quase que completa da minoria branca, por um "processo de miscigenaçăo e de capilaridade social" (RAMOS, 1995, p.175). A sua compreensăo da branquitude no Brasil o leva a afirmar que "nâo há mais entre nós coincidência entre raça e classe" (RAMOS, 1995, p.173). Conforme o historiador Joel Rufino dos Santos (1997), Guerreiro Ramos concluiu que "o problema do negro" era um sintoma da patologia do branco, e, sem negar as problemáticas negra e indígena, argumentou que ou se considerava o negro como protagonista social e político, sem distingui-lo do autodenominado branco, ou nada.

Ademais, o racismo e a discriminaçăo racial săo constitutivos da formaçăo da sociedade brasileira e operam menos no plano individual e mais no plano institucional e estrutural (SILVÉRIO, 2002). O racismo opera o processo de racializaçâo, no qual 
a "raça" "deve ser considerada como constitutiva, e năo como desdobramento e/ou consequência, ou mesmo uma anomalia da modernidade" (SILVÉRIO, 2018, p. 278). A raça é uma construçâo social de representaçōes baseadas em um processo ontológico cindido que estabelece a condiçăo de superioridade àqueles considerados brancos e, aos negros, a inferioridade nas dimensōes do ser, do saber e do poder (DU BOIS, 1999; GILROY, 2001; FANON, 2008; HALL, 2016, SILVÉRIO, 2018; BERNARDINO-COSTA; MALDONADO-TORRES; RAMÓN GROSFOGUEL, 2018).

Assim, a branquitude, neste processo de reflexăo crítica, se refere à forma como os sujeitos brancos se apropriam da categoria raça e do racismo na constituiçăo de suas subjetividades e ao se apropriarem acreditam que "ser branco" determina características morais, intelectuais e estéticas dos indivíduos que os distinguem de outros e os asseguram silenciosamente posiçôes de superioridade na hierarquia social, sem que isso seja encarado como um privilégio. É nesse contexto, que este artigo propóe uma discussăo crítica sobre a branquitude.

E, também, a branquitude é entendida como uma construçâo social de significados, um lugar de neutralidade e superioridade racial do branco, bem como de expressáo de poder e privilégio racial, econômico, político, social, material e simbólico (AZEVEDO, 1987; FRANKENBERG, 2004; BENTO, 2014; SCHUCMAN, 2012; PIZA, 2014; CARONE, 2014, PIZA; ROSEMBERG, 2014;). Um lugar de vantagem estrutural nas sociedades estruturadas na dominaçăo racial, que se desloca dentro de denominaçóes étnicas ou de classe (FRANKENBERG, 2004; BENTO, 2014) e que é protegido por um silêncio que năo é apenas o náo-dito, mas aquilo que é apagado, colocado de lado, excluído, ou seja, pelo silêncio da opressáo (BENTO, 2011).

Em razăo disso, esta reflexăo crítica sobre a branquitude é proveniente dos estudos de W.E.B Du Bois e Frantz Omar Fanon, por demonstrarem os impactos da construçáo social da raça, no contexto da modernidade ocidental, sobre a populaçâo de origem africana no processo de escravidăo, na formaçăo dos estados nacionais a partir de um empreendimento colonial de estrutura racista que codificou a branquitude como norma, modelo de humanidade, autoridade, racionalidade, civilizaçăo e cultura, tornando-se, dessa forma, uma ideologia necessária para justificar o processo de escravidăo dos povos africanos e autóctones, bem como a própria colonizaçăo e a expansăo do capitalismo.

Esses estudiosos destacam que o modelo colonial, além de significar a imposiçâo da força, domínio e supremacia branca, implicou na negaçăo do ser àquele que foi designado de negro, e, por consequência, a sua opressáo, degradaçăo social e hierarquizaçăo social e imersăo em um complexo de inferioridade. Desse modo, sem utilizar precisamente o termo colonialidade, é possível encontrar a ideia que gira em torno desse conceito em toda a tradiçáo do pensamento de Du Bois (1999) e Fanon (1968; 2008), na medida em que mostram que a diferença, a desigualdade e a hierarquizaçăo entre os povos colonizados deu-se a partir da ideia de raça, pelo projeto eurocêntrico da modernidade. Diante disso, os estudos Decoloniais, Pós-coloniais e da Diáspora ajudam a pensar que as diferenças precisam ser reinventadas a partir de um diálogo crítico das identidades marcadas.

Estudiosos, ativistas e intelectuais que integram o projeto de investigaçăo modernidade/decolonialidade discutem a importância da raça como dimensăo estruturante 
do sistema-mundo moderno colonial e o racismo como um princípio constitutivo que organiza todas as relaçóes de dominaçáo da modernidade, que estabelece desde uma linha divisória entre aqueles que têm o direito de ser e de viver, e os que nâo o têm, a exemplo do genocídio da juventude negra nas periferias das grandes cidades brasileiras, até as hierarquias de dominaçăo: raciais, sexuais, de gênero, religiosas e epistêmicas. Ou seja, o racismo é também um princípio organizador daqueles que podem formular um saber científico legítimo e daqueles que năo o podem, de modo que a hierarquia epistêmica resulta em negaçâo ontológica. E, por isso, sistematizam o conceito de geopolítica e corpo-política do conhecimento como crítica ao eurocentrismo e ao cientificismo (BERNARDINO-COSTA; MALDONADO-TORRES; GROSFOGUEL, 2018; MIGNOLO; ESCOBAR, 2010; QUIJANO, 2005).

Além disso, também subsidiam este pensamento crítico e reflexivo sobre a branquitude, estudiosos mais contemporâneos que, segundo Faustino (2015), mobilizam o pensamento de Frantz Fanon em suas diversas abordagens teóricas², a saber: Estudos Pós-coloniais e da Diáspora: Stuart Hall, Paul Gilroy, Valter Roberto Silvério, Antônio Sérgio Guimaráes; Decoloniais: Ramón Grosfoguel, Nelson Maldonado-Torres; e Branquitude: Maria Aparecida Bento.

Igualmente como Maria Aparecida Bento, pesquisadoras como Azevedo (1987), Piza (2014), Carone (2014), Rosemberg (2014) e Schucman (2012) realizam um estudo crítico da branquitude no Brasil, destacando o mito da democracia racial e o ideal de branqueamento como características centrais da sociedade brasileira quando se trata de relaçóes raciais, e, portanto, como mecanismos racistas de produçâo de desigualdades sociais que asseguraram aos brancos a ocupaçăo de posiçóes mais elevadas na hierarquia social, sem que isso fosse considerado como poder e privilégio racial.

\title{
1. O CAMPO DE ESTUDOS CRÍTICOS SOBRE A BRANQUITUDE
}

\begin{abstract}
A separaçấo social das raças tratava-se da ruptura súbita de quase todas as relaçôes entre brancos e negros no trabalho, no governo, na vida familiar. Desde entăo, tem-se propagado um novo ajustamento de relaçóes em questóes econômicas e políticas - um ajustamento sutil e difícil de compreender e, contudo, singularmente engenhoso, em que ainda persevera aquele temível abismo do preconceito cuja transposiçăo é extremamente arriscada. (DU BOIS, 1999, p. 150-151)
\end{abstract}

Os estudos críticos sobre a branquitude (critical whiteness studies) fazem uma inversâo epistemológica, ou seja, um movimento de deslocamento do grupo social racializado como negro para o centro sobre o qual foi construída a ideia de raça, isto é, para o branco. Isso porque, por certo, a falta de reflexâo sobre o papel do branco nas desigualdades raciais é uma forma de reiterar persistentemente que essas desigualdades constituem um problema exclusivamente do negro, pois só ele é estudado, dissecado, problematizado, e, portanto, uma forma de impedir o avanço da luta por uma sociedade mais igualitária (BENTO, 2014).

2 O estudo de Faustino (2015) traz as apropriaçôes do pensamento de Frantz Fanon no Brasil a partir da década de 1950 em suas diversas abordagens teóricas. 
Ademais, esses estudos também se formam como um campo transnacional, visto que corresponde à história das formaçóes e construçóes de Estados-Naçăo da Modernidade, ou seja, a história do colonialismo europeu e seu sistema mundo colonial racista, segregado, opressor, violento e escravista. É nesse processo histórico que a branquitude começa a ser construída como um constructo ideológico de poder, em que os brancos tomam a sua identidade racial como norma e padráo e, dessa forma, outros grupos aparecem como inferiores.

Nesse viés, Hall (2016) interpreta os signos nos termos da ideologia social, que se refere aos referenciais mentais - crenças gerais, linguagens, quadros conceituais, categorias e sistemas de valores da sociedade - que sustentam tanto o poder e a dominaçáo quanto a subordinaçăo de grupos sociais. E, ainda, Hall argumenta que a construçấo de conceitos e signos é arbitrária e produzida em contextos históricos e culturais específicos e, que, portanto, o sentido ou o conceito muda historicamente e nunca é fixado de forma definitiva, e, por conta disso, o regime ideológico e racializado de representaçăo deve ser ativamente lido, interpretado e contestado como forma de levar à emancipaçăo.

W. D. B. Du Bois foi um dos estudiosos da identidade racial branca nos Estados Unidos. Sua concepçâo de branquitude como terror e supremacia, denuncia o terror racializado e racializante durante e pós-escravidăo e a cumplicidade da racionalidade com as contradiçōes da modernidade. Para Gilroy (1993), o status de primeiro sociólogo negro e pioneiro da disciplina na América é uma importante razâo para a importância do estudo de Du Bois, pois sua sociologia também traz a marca de sua ambivalência, pelo fato de que "ele também era um negro americano e os problemas da ontologia e da identidade racializada - a tensâo entre ser e tornar-se negro - estâo, portanto, profundamente gravados na própria vida de Du Bois" (GILROY, 2001, p. 115-116).

Em The Souls of Black Folk (As Almas da Gente Negra), livro publicado em 1903, aos 35 anos, que o converteu em líder dos negros americanos, Du Bois fala da experiência dos negros na América, um povo envolto nas dobras do véu da cor, fala diretamente aos brancos americanos, desafiando seu sentido de civilizaçăo e de cultura nacional, codificadas pela cor, e também, à comunidade transnacional tanto no presente quanto no futuro (GILROY, 2001).

O entendimento de Du Bois da relaçăo entre raça, naçăo e cultura e a atençăo dada à dinâmica específica da subordinaçâo racial produziu uma teoria da açâo política na qual era rejeitada a prioridade das relaçôes de classe e era demonstrada a autonomia dos fatores culturais e ideológicos em relaçăo à determinaçăo econômica (GILROY, 2001). Assim, Du Bois inicia e termina o capítulo II afirmando que o problema do século XX é o problema da barreira racial, que, por sua vez, impediu a oportunidade humana, de ser, tanto aos negros quanto aos brancos. Assim, a identidade racial branca assumiu a condiçăo humana por meio das leis e dos costumes enquanto classificava o negro como semi-homem, portanto, como uma classe servil segredada com direitos e privilégios restritos. No capítulo III, Du Bois critica o programa de educaçâo técnica industrial para os negros proposta por Booker T. Washington, como limitada, ajustada à política de submissăo do negro e contrária ao direito inalienável de todos à educaçăo, inclusive, à educaçăo superior cuja finalidade é a cultura e o desenvolvimento humano.

Nos capítulos IV a IX, de foco sociológico, Du Bois (1999) faz reflexóes sobre os sentidos do conceito de progresso, considerou-o necessariamente feio e năo mais 
significativo que a vida de amor, luta, esforço e fracasso na interaçăo dos negros, e, ao mesmo tempo, tăo humana e real. Ademais, usa as expressōes: Sombra do Véu, Linha de Cor e Cinturâo Negro, para desenvolver uma crítica à segregaçăo racial e seus efeitos na vida, bem como na educaçấo dos negros dentro de uma sociedade branca com ideias e valores brancos. Nesse contexto, Du Bois (1999) argumenta que os preconceitos de raça, os quais mantem os homens escuros e negros em seus "lugares", săo aliados da ambiçăo e adoecimento dos seres humanos que lutam. "E, sobretudo, escuta-se diretamente que uma educaçáo que estabeleça como meta os locais mais elevados e que privilegie como finalidades a cultura e o caráter em vez do ganha-páo constitui o privilégio dos brancos" (DU BOIS, 1999, p. 149).

Aliado a isso, nos últimos capítulos do livro, Du Bois destaca a importância do deslocamento, do movimento nos relatos de suas viagens pelo Sul, acentuado por expressóes como o trem, o vagăo dos negros, o cabineiro, a continuidade da viagem, as curvas na estrada, o ziguezague dos trilhos, as terras Sem-Cerca. Nesse viés, Du Bois oferece um meio para lê-lo como uma narrativa de emersăo da particularidade racial. "O mais importante é que essa parte do livro pode ser interpretada como um convite à fuga năo apenas do Sul ou mesmo da América, mas dos códigos fechados de todo entendimento restritivo ou absolutista da etnia" (GILROY, 2001, p. 269). Dessa forma, a crítica de Du Bois (1999) ao racismo e ao preconceito como representaçâo estereotipada e negativa do negro na sociedade branca norte-americana, é também uma luta pela transformaçáo e realizaçấo do ser e estar negro no mundo.

No livro O Atlântico Negro (2001), o sociólogo inglês Paul Gilroy aspira por um movimento político contemporâneo contra as obsessóes da pureza racial e a representaçăo do corpo humano como repositório fundamental da ordem da verdade racial, resultantes em sociedades racialmente estruturadas e relaçôes sociais de subordinaçâo racial e impostas pelos Estados-naçóes modernos e ocidentais. Assim, propóe a desterritorializaçáo da cultura devido à hibridez, ao movimento, à troca e ao inacabamento contínuo das identidades, em oposiçâo à ideia de uma cultura fechada e codificada no corpo. Nesse sentido, a imagem do navio remete a "um sistema vivo, microcultural e micropolítico em movimento e concentra a atençâo nos vários projetos de retorno redentor para uma terra natal africana, na circulaçáo de ideias e ativistas, bem como no movimento de artefatos culturais e políticos chaves: panfletos, livros, registros fonográficos e coros" (GILROY, 2001, p. 38).

Assim, Gilroy (2001) analisa a política cultural do Atlântico Negro e a dispersâo africana no hemisfério ocidental, a partir do conceito de diáspora, importado de inconfessadas fontes judaicas e utilizado năo como uma dispersâo catastrófica, e sim como um processo que redefine a dinânica cultural e histórica do pertencimento. Representa a desracializaçáo global do pensamento com ruptura temporal, espacial e ontológica e a recriaçăo de sujeitos e culturas apagados. "Sob a chave da diáspora nós poderemos entăo ver năo a "raça", e sim formas geopolíticas e geoculturais de vida que sâo resultantes da interaçáo entre sistemas comunicativos e contextos que elas nâo só incorporam, mas também modificam e transcendem" (GILROY, 2001, p. 25). E, ainda conforme o autor, permite construir uma resposta ao racismo que năo reifique o conceito de raça e premiar a sabedoria gerada pelo desenvolvimento de respostas ao poder do absolutismo étnico, que năo tente fixar absolutamente a etnia, mas a veja como um processo infinito de construçâo da identidade. 


\section{ESTUDOS CRÍTICOS SOBRE A BRANQUITUDE NO BRASIL}

A identidade racial branca também foi pensada criticamente por Frantz Omar Fanon, filósofo e psiquiatra na França, que foi um ativista, revolucionário, militante de esquerda na Martinica e conhecido internacionalmente como intelectual anticolonial, participando ativamente dos debates internacionais sobre a libertaçăo dos países colonizados. Se designava como um antilhano de origem, originário de várias colônias, neto de escravos e que chegou neste mundo sem verdades decisivas no ano de 1925, em uma colônia francesa no Caribe chamada Martinica. Morreu em 1961 com 36 anos nos Estados Unidos.

Faustino (2015), no estudo Por que Fanon, por que agora? discute as diferentes apropriaçóes do pensamento de Fanon no Brasil a partir da década de 1950 e constata que o legado de Fanon é reivindicado de maneira diversa por perspectivas teóricas distintas que se configuram em seis subcampos: 1) Estudos Pós-coloniais e da Diáspora; 2) Negritude; 3) Decoloniais; 4) Branquitude; 5) Psicologia; 6) Ethos Nacional. Para esse autor, os estudos sobre branquitude no Brasil fazem referência a Fanon, sendo o mais antigo o trabalho de Maria Aparecida Bento, de 2002, que retoma Fanon para problematizar a introjeçâo do medo e dos estereótipos racistas em relaçăo aos negros por parte dos brancos. Na perspectiva decolonial, há aproximaçâo de Fanon em estudos de Paulo Freire e Guerreiro Ramos. Assim, Fanon náo é buscado apenas como informante a ser analisado, mas também como referencial privilegiado para pensar os conflitos contemporâneos (FAUSTINO, 2015).

As obras de Fanon, como: Peau noire, masques blancs (Peles negras, máscaras brancas) publicado em 1952 e Les damnés de la terre (Os condenados da terra) publicado em 1961, sâo consideradas como clássicas e com presença no cânone filosófico da Diáspora Africana. Sua concepçăo de branquitude como superioridade branca, terror e opressăo colonial mostra os efeitos do colonialismo na desestruturaçâo da vida das populaçôes autóctones colonizadas a partir da ideia de raça.

O conceito de raça ou racializaçâo é entendido como uma construçăo social utilizada pela humanidade para classificar e hierarquizar os grupos humanos e as relaçóes sociais a partir da definiçấo de diferenças fenotípicas observáveis (cor da pele, formato do nariz, lábios, tipo e cor de cabelo). Sobre a racializaçâo, Silvério (1999) diz que o conceito está relacionado ao modo como se concebe a ideia de raça. Para alguns, a racializaçăo é uma característica erradicável das sociedades humanas, e, para outros, ela aparece como um processo lógico-ideal constitutivo da modernidade, afirmando ainda que, desde o século XVIII, a populaçâo mundial tem sido classificada no pensamento europeu em "raças", nâo em termos de definiçấo, mas em termos de processos de formaçăo racial. Assim, "se raça năo é algo natural ou inato ou uma ilusăo, importa saber as razóes e condiçóes nas quais o discurso sobre raça é empregado na tentativa de rotular, constituir, excluir ou incluir subalternamente coletividades sociais" (SILVÉRIO, 1999, p. 09). Nesse sentido, o conceito teórico de raça é removido definitivamente do reino biológico para o reino social, onde a branquitude continua sendo uma matéria de preocupaçâo.

Fanon (1968) desenvolve o conceito de racializaçâo como um processo de dimensâo global implementado pelo colonialismo, juntamente com um debate sobre o papel e os desafios dos intelectuais africanos no processo de luta pela descolonizaçăo e construçăo de uma cultura nacional autêntica no pós-colonialismo, a fim de "romper as rédeas 
do colonialismo (FANON, 1968, p. 172). Argumenta, portanto, que o colonialismo reservou igualmente ao negro um complexo de inferioridade, e ao branco um complexo de superioridade na hierarquizaçăo social, que deve ser combatido globalmente. Nessa perspectiva, é possível compreender que raça é uma categoria construída e inerente ao projeto de dominaçăo colonial - econômico e social - pois nâo haveria outra razăo para as pessoas se pensarem em termos raciais.

Segundo Fanon, o colonialismo é estruturalmente racista, de modo que o racismo está inscrito na estrutura social, econômica, histórica e cultural das sociedades ocidentais e racializou as posiçóes sociais ao classificar as pessoas com base em um modelo de homem branco/europeu/ocidental/colonizador. Desse modo, na perspectiva fanoniana, o racismo é um dos elementos de opressăo inerentes à dominaçâo colonial, usado para transformar o colonizado em objeto dos propósitos do colonizador e, assim, afirmar a superioridade racial branca.

O colonizado é estereotipado negativamente como negro, tem sua originalidade cultural e dimensôes humanas negadas e é levado a um processo de epidermizaçâo da sua inferioridade em relaçăo ao branco colonizador que se apropriou da condiçăo de ser humano, portanto, de superioridade (FANON, 1968; 2008). O resultado dessa ontologia cindida seria um sentimento de superioridade racial dos brancos em relaçăo aos năo brancos e a năo realizaçăo do branco e do negro enquanto ser. Fanon mostra que o colonialismo firmou a supremacia dos valores brancos através da violência em estado bruto usada para explorar, oprimir, deformar, aniquilar, e desumanizar o colonizado. E ainda, dividiu o mundo colonial em dois campos: o branco e o negro, por sua vez, dicotômicos, segregados, destrutíveis e de exclusâo recíproca.

Fanon ajuda a entender que a ideia de raça determina a cultura. Argumenta que o colonialismo esvaziou o cérebro do colonizado de toda forma e conteúdo para provocar a alienaçấo cultural, ou seja, uma perda de si subordinada ao colonialismo que resultaria no desejo do negro em embranquecer, em tornar-se branco. Assim, a supremacia da cultura branca se impôs à incultura dos outros racializados. Năo satisfeito, "o opressor ainda se esforça para levar o colonizado a confessar a inferioridade de sua cultura transformada em condutas instintivas, a reconhecer a irrealidade de sua naçâo e, finalmente, o caráter inorganizado e inacabado de sua própria estrutura biológica" (FANON, 1968, p. 198).

Essa relaçăo entre colonizador (branco) e colonizado (negro) também foi discutida no Brasil pelo sociólogo Alberto Guerreiro Ramos ao estudar a branquitude como invisibilizaçăo e normalizaçăo na sociedade brasileira, bem como os efeitos do racismo e da ideologia do branqueamento para o próprio branco brasileiro. Guerreiro Ramos, em Introduçăo Crítica à Sociologia Brasileira, publicado em 1957, elaborou no terceiro capítulo uma discussăo intitulada Patologia social do "branco" brasileiro, onde faz uma proposta de inversăo no estudo das relaçóes sociais no Brasil, ou seja, do "problema do negro" para o "branco" brasileiro. Isso porque, nas condiçóes de formaçăo colonial da sociedade brasileira, a ideologia da brancura era dominante como critério de estética social enquanto a desvalorizaçăo estética da cor negra, ou melhor, da associaçăo desta cor ao feio, ao degradante, a um sistema de estereótipos e a posiçōes inferiores, apresentava-se como normal, ao mesmo tempo em que se constituíam como um dos suportes psicológicos da espoliaçáo por parte de uma minoria branca europeia (RAMOS, 1995). 
A idealizaçăo da brancura, na sociedade brasileira, ainda sobrevive e é sintoma de escassa integraçấo social de seus elementos, é sintoma de que a consciência da espécie entre os que a compóem mal chegou a instituir-se. Este, porém, é um processo social normal que năo poderá ser definitivamente obstaculizado. Apenas uma situaçăo colonial temporária tem embaraçado este processo. (RAMOS, 1995, p. 191)

Ademais, para Guerreiro Ramos, o estudo do negro como objeto e náo como sujeito pela sociologia da época também seria uma patologia social, visto que "o problema do negro" é reflexo da patologia social do "branco" brasileiro, de sua dependência psicológica" (RAMOS, 1995, p. 192). E, ainda, o autor traz no título a palavra branco entre aspas para enfatizar que, no Brasil, o branco puro, sem nenhuma mistura cultural e biológica com a cultura afro-brasileira é excepcional, e a patologia seria uma tendência a negaçấo dessa condiçấo étnica por parte do branco brasileiro. Esse imaginário social brasileiro da ideia de superioridade da identidade racial branca tenderia ao branqueamento, ou seja, o brasileiro pardo com certo grau de instruçấo, tenderia a se classificar como branco, o negro como pardo-moreno e à recusa do branco à mistura biológica e cultural com o negro como uma forma de fugir dos estereótipos negativos que posicionavam os negros como inferiores na hierarquia social brasileira.

Feres Júnior (2015) argumenta que a reflexăo sobre relaçôes raciais no Brasil feitas por Guerreiro Ramos na década de 1950, como a crítica à branquitude ligada a um projeto emancipador de naçăo, continuam atuais, visto que elementos desse conceito como: a invisibilidade e normalizaçăo da ideologia da superioridade racial dos brancos vinculada a um sistema de pseudojustificaçôes de estereótipos que perpetuam a inferiorizaçâo e a discriminaçăo da maioria, ainda é hegemônica.

Guerreiro Ramos critica a invisibilizaçăo, universalizaçăo e normalizaçăo da nacionalidade branca europeizante e ocidentalizante no Brasil incutidos pelo processo de colonizaçăo e escamoteados através de mitos como o da democracia racial, uma versăo de branquitude reputada a Gilberto Freyre, que idealizava uma naçăo etnicamente homogênea ao mesmo tempo em que preservava as diferenças raciais (FERES JÚNIOR, 2015). Portanto, Feres Júnior (2015) argumenta que, para Guerreiro Ramos, o branco, ou seja, a versăo 2.0 e otimizada de colonizador europeu e muito mais sofisticada, produzida aqui no Brasil, é um obstáculo ao progresso da naçăo, à emancipaçáo do Brasil como povo capaz de escolher seu próprio destino e suas próprias formas de existência.

A historiadora Célia Maria Marinho Azevedo, em sua obra Onda negra, medo branco (1987), fala do ideal de branqueamento brasileiro atrelado ao medo. Desse modo, investigou a dimensáo histórica do medo "de brancos "esfolados" bem-nascidos e bem-pensantes que, durante todo o século XIX, realmente temeram acabar sendo tragados pelos negros malnascidos e mal pensantes" (AZEVEDO, 1987, p. 18). Pode-se dizer que a autora desenvolve uma concepçáo de branquitude como a superioridade do padráo racial dominante branco, alimentada pelo imaginário do medo e forjada pela ideia da inferioridade racial da populaçăo nacional (majoritariamente ex-escrava de origem africana e afrodescendente) em termos biológicos certificados por teorias raciais científicas e relacionada à representaçâo negativa do negro no sentido de tendente ao crime, barbárie, imoralidade, irracionalidade, vagabundagem, indisciplina, ociosidade e à incapacidade ao trabalho. 
Como resultado, conforme Azevedo (1987), esse medo gerou uma política racista e preconceituosa de incentivos e favorecimentos continuados à imigraçăo europeia por parte do Estado brasileiro no final do século XIX, cuja consequência foi trazer para o Brasil milhóes de imigrantes europeus, vistos como civilizados, racionais, inteligentes, enérgicos, responsáveis. O imigrante europeu seria o trabalhador ideal, livre e qualificado para a industrializaçăo do país ou o tipo racial adequado para a substituiçăo do negro, a purificaçâo da raça brasileira e a formaçăo de uma identidade nacional etnicamente purificada, sendo a purificaçăo racial entendida como "a substituiçâo do negro pelo branco nos setores fundamentais da produçăo, como também, a esperança de um processo de miscigenaçăo moralizadora e embranquecedora" (AZEVEDO, 1987, p. 144).

Para Azevedo (1987), nesse contexto, esboçava-se a tese do branqueamento, apontando para o momento em que o elemento considerado racialmente superior conseguiria ser predominante na populaçâo nacional. E, ainda, começava-se a delinear muito nitidamente a figura do brasileiro como resultado da mistura racial tăo vivamente descrito por Gilberto Freyre em Casa Grande e Senzala. E, dessa forma, a imagem de um país imerso em ódios sociorraciais, que negou ao negro a condiçâo de sujeito da história, era assim substituída em um curto espaço de tempo por outra, radicalmente distinta, a de um paraíso racial. Todavia, a sociedade brasileira era dividida racialmente, ou seja, era discriminatória em termos raciais.

Como bem lembra Fanon (2008), o processo de branqueamento imposto ao negro tem em seu cerne o preconceito e a discriminaçâo racial como meio de manutençâo da superioridade da raça branca. Nesse sentido, "embranquecer a raça, salvar a raça, mas năo no sentido que poderíamos supor: năo para preservar "a originalidade da porçâo do mundo onde elas cresceram", mas para assegurar sua brancura" (FANON, 2008, p. 28).

Ainda sobre o branqueamento como uma dimensāo da branquitude, Iray Carone, no estudo sobre as relaçóes raciais no Brasil, intitulado A formaçăo psicológica do legado social do branqueamento-um estudo sobre a negritude em Săo Paulo, desenvolvido no período de 1992 a 1996 financiado pela Unesco, constata a falsa democracia racial na realidade brasileira e a presença da ideologia do branqueamento já deslocada da visăo de Gilberto Freyre. Com efeito, o branqueamento pode ser entendido como resultado da miscigenaçăo entre brancos e negros no período colonial responsável pelo aumento superior de mestiços em relaçâo a negros e brancos na composiçấo racial da populaçăo brasileira, e, também como uma pressáo cultural exercida pela hegemonia branca, sobretudo após a aboliçăo da escravatura, para que o negro negasse a si mesmo, no corpo e na mente, como condiçăo para ter aceitaçăo e mobilidade social na nova ordem social (CARONE, 2014).

A miscigenaçăo entre negros e brancos, exaltada por Gilberto Freyre como um embriăo da 'democracia racial' brasileira e base de nossa identidade nacional - 'povo mestiço','moreno' - foi parte da escravidâo colonial. Mas o cruzamento racial năo foi um processo natural, e sim determinado pela violência e exploraçáo do português de ultramar contra o africano sob o cativeiro. (CARONE, 2014, p. 14)

Jerry Dávila, no livro Diploma de brancura: política social e racial no Brasil (19171945), traz um estudo das relaçóes raciais no Brasil a partir da educaçấo, no qual conclui 
que as reformas educacionais conduzidas pela elite intelectual brasileira, a saber: educadores, intelectuais, cientistas sociais, médicos, expressavam um imaginário racial de construçấo de uma naçăo social e culturalmente branca. O ministro da Educaçăo e Saúde, Gustavo Capanema, defendia a ideia da superioridade da "raça branca" em uma perspectiva cultural. A educaçăo seria um meio de transmissăo de noçóes básicas de saúde, higiene, comportamento e cultura, para embranquecer a naçăo e permitir que todos, independentemente de sua cor, fossem elevados à condiçâo de brancos. Na visăo dos reformadores da educaçáo, educar significava melhorar e progredir, que, por sua vez, era equiparado a embranquecer, de maneira que o sistema educacional brasileiro do período da Primeira República à Era Vargas foi refratário à inclusăo racial, limitou as oportunidades educacionais de pessoas negras e legitimou as desigualdades sociais entre pessoas brancas e negras no Brasil.

Nos anos de 1970, os privilégios materiais da branquitude na sociedade brasileira sâo demonstrados nas pesquisas das relaçóes e das desigualdades raciais realizadas por Silva e Hasenbalg (1992), até a segunda metade dos anos de 1970, as desigualdades raciais sâo tratadas como: 1) um náo-problema em decorrência da ideologia da democracia racial freyreana, até 1930; 2) um problema de classe influenciado pela perspectiva reducionista de Freyre, nas décadas de 1940-1950; 3) um reflexo epifenomênico da estrutura econômica (classe social, estrutura e dominaçấo de classe), ou como um meio usado pela classe dominante para dividir os trabalhadores, na década de 1960; e 4) a partir de 1970, como um esquema classificatório e um princípio de seleçâo racial que está na base da persistência e reproduçăo de desigualdades sociais e econômicas entre brasileiros brancos e năo brancos. Nesse viés, a variável raça năo é socialmente neutra e sem consequências, é, por certo, fator determinante nas oportunidades de vida e na hierarquizaçăo social.

\begin{abstract}
Partindo desta nova ótica, é possível propor a ideia de que a raça ou a filiaçâo racial deve ser tratada como uma variável ou critério que tem um peso determinante na estruturaçăo das relaçóes sociais, tanto no sentido objetivo quanto subjetivamente. Objetivamente, na medida em que a raça é um determinante importante das chances de vida das pessoas. Subjetivamente, no sentido do pertencimento racial (mesmo náo sendo, no caso do Brasil, um atributo unívoco e sim mais relacional e situacional) estar associado a identidades raciais que implicam uma socializaçăo e aprendizado do lugar de diferentes grupos raciais no espaço e hierarquizaçăo sociais. (SILVA; HASENBALG, 1992, p. 11-12)
\end{abstract}

Nesse sentido, Silva e Hasenbalg (1992) estudam a relaçăo entre raça e oportunidades educacionais no Brasil a partir de informaçôes da Pesquisa Nacional por Amostra de Domicílio (PNAD) de 1982, e mostram a desigual apropriaçáo das oportunidades educacionais por parte de brancos e negros e os efeitos acumulados do racismo e da discriminaçâo racial no âmbito da educaçáo formal. Desse modo, apontam que, entre os brancos, a taxa de analfabetismo é duas vezes menor do que a dos negros, a dificuldade de acesso às escolas, ingresso tardio, permanência e continuidade nos estudos é maior entre os negros, mesmo quando na mesma origem social ou renda familiar per capita que os brancos, e, estes, apresentam sete vezes mais probabilidade que os negros de completar estudos universitários. Com efeito, esses mecanismos racistas fazem com que os brancos ocupem o topo da hierarquia social e 
posiçōes na estrutura de classes que contêm privilégios materiais e simbólicos mais almejados (SILVA; HASENBALG, 1992).

Assim, é como bem diz Silvério (2002) que o problema da desigualdade social entre brancos e negros deve ser explicada pelo racismo e discriminaçăo racial configurados como racismo institucional legitimado pelo Estado. Por fim, é necessário pensar que as desigualdades raciais nâo estăo dissociadas da construçâo social silenciosa da branquitude, inclusive pelas instituiçôes públicas, ou seja, de um imaginário social em torno da ideia de raça que faz com que sujeitos considerados brancos obtenham diferentes dimensóes do privilégio em uma sociedade estruturalmente racista.

\section{O CONCEITO DE BRANQUITUDE}

Sou branco, quer dizer que tenho para mim a beleza e a virtude, que nunca foram negras. Eu sou da cor do dia [...] (FANON, 2008, p. 56)

A definiçăo de branquitude e quem săo os sujeitos que ocupam lugares sociais e subjetivos da branquitude está presente em estudos recentes no Brasil. Pesquisas realizadas por Iray Carone, Maria Aparecida Silva Bento, Edith Piza, Lia Vainer Schucman, dentre outros na área da Psicologia Social, vêm abrindo novas possibilidades de investigaçâo sobre a constituiçấo da branquitude no Brasil, ou seja, da identidade racial do branco brasileiro - "um continente a ser explorado por aqueles que reconhecem a importância política de se focalizar cientificamente o preconceito e a discriminaçâo racial nas relaçōes sociais" (CARONE, 2014, p. 22).

E, ainda, conforme Iray Carone, o ano de 1994 marca o início de uma interpretaçấo da realidade racial brasileira já deslocada da visâo luso-tropicalista de Gilberto Freyre, bem como da literatura corrente escrita por brancos a respeito de negros no Brasil nos anos de 1950. Esse deslocamento possibilitou uma mudança na busca do conhecimento: o foco da discussáo é o lugar que o branco ocupou e ocupa nas relaçóes raciais brasileiras.

Foi aí que começamos a descobrir os segredos da branquitude. Retratos dessa jornada branquitude adentro permitiram esboçar os privilégios nunca ditos, os medos paranoicos, as pulsóes negadas e projetadas para fora, os racismos inconfessos dos sujeitos brancos. (CARONE, 2014, p. 22)

Bento (2014) aborda as dimensōes da branquitude a partir do tema branqueamento e branquitude no Brasil, explorando questôes relacionadas ao padrăo ideal de branqueamento inventado pela elite branca, e, por esta, apresentada à sociedade brasileira como um problema do negro. Para isso, a elite fez uma apropriaçăo simbólica de si como referência humana como meio de legitimar sua supremacia econômica, política e social, ao mesmo tempo em que investiu na construçâo de um imaginário social negativo sobre o negro, com a finalidade de destruir a sua identidade racial, danificar sua autoestima e responsabilizá-lo pela discriminaçăo sofrida e, por fim, justificar as desigualdades raciais.

Nesse estudo, o conceito de branquitude é abordado como a supremacia econômica, política e social do branco brasileiro e suas características e mecanismos de preservaçâo da discriminaçáo racial e manutençáo das desigualdades raciais. Bento 
(2014) aponta algumas características, aspectos importantes da branquitude que se constituem como estratégias de preservaçâo da discriminaçấo e desigualdade racial, que podem ser identificadas como:

1) os pactos narcísicos entre os brancos de năo se reconhecerem como parte essencial na permanência das desigualdades raciais no Brasil. Um pacto de invisibilidade, silêncio, omissâo e distorçâo acompanhado de um investimento na imposiçấo do modelo de si mesmo, isto é, da identidade racial branca como referência da condiçâo humana. Com efeito, esse tipo de acordo tem implicaçōes. "No contexto das relaçôes raciais visa justificar, legitimar a ideia de superioridade de um grupo sobre o outro e, consequentemente, as desigualdades, a apropriaçăo indébita de bens concretos e simbólicos, e a manutençăo de privilégios" (BENTO, 2014, p. 31).

2) o medo gerado pelo negro na elite branca brasileira é outra característica importante da branquitude, pois o medo e a projeçâo podem estar na gênese de processos de estigmatizaçâo de grupos, para legitimar a perpetuaçâo das desigualdades, de relaçōes raciais hierarquizadas, de elaboraçâo de políticas institucionais racistas e preconceituosas, como as políticas de imigraçâo europeia no final do séculos XIX com vistas à exclusâo total dos negros libertos do processo de industrializaçăo e ao propósito de branqueamento do Brasil. "Talvez possamos concluir que uma boa maneira de se compreender melhor a branquitude e o processo de branqueamento é entender a projeçăo do branco sobre o negro, nascida do medo, cercada de silêncio, fiel guardiăo dos privilégios" (BENTO, 2014, p. 39).

Fanon (2008), no capítulo intitulado de O preto e a psicopatologia, diz que a estigmatizaçăo do negro e o processo de projeçấo na construçăo do preconceito racial do branco contra o negro é resultado da situaçăo colonial, em que, de forma lenta e sutil, por meio da educaçâo, dos livros escolares, do cinema, das revistas ilustradas infantis escritas por brancos e lidos por nativos, o preto ou o índio é representado pelo Lobo, Diabo, Gênio do Mal, o Mal, o Selvagem, e havendo identificaçấo com o vencedor, o preto se comporta subjetivamente e intelectualmente como o branco e, assim como o branco, passa a correr o risco de ser devorado pelo negro. Fanon (2008) enfatiza também que o medo do europeu era o medo da sexualidade projetada sobre o negro. O preto é representado no plano do imaginário como perigo biológico, a potência genital acima da moral. Portanto, "ter fobia do preto é ter medo do biológico" (FANON, 2008, p. 143).

3) a invisibilidade do branco nos estudos sobre relaçóes raciais no Brasil, o papel que o branco ocupa, como branco, na perpetuaçấo das desigualdades raciais e dos privilégios simbólicos e materiais da brancura, é uma característica da branquitude (BENTO, 2014). Em virtude disso, os estudos sobre o branqueamento no negro associam-no ao desejo de ascensáo social como se a sociedade de classes fosse um mundo dos brancos onde o negro năo pode penetrar. Bento (2014) esclarece que, no Brasil, a teoria do branqueamento, a industrializaçăo e uma populaçáo majoritariamente negra e liberta, se coincidem gerando o medo do diferente que poderia monopolizar os postos de trabalho. Assim, o negro "foi tratado como um ser despreparado para integrar a sociedade de 
classes ou como um trânsfuga que manipulava sua condiçăo racial para poder ascender" (BENTO, 2014, p. 52).

Edith Piza (2014) também aponta a invisibilidade como uma característica da identidade racial branca, que consiste no náo reconhecimento do branco como ser racializado e do negro como raça. Essa compreensăo é tida como natural, e é construída na relaçâo social, que, por sua vez, é racista. As consequências dessa posiçấo de invisibilidade, năo se identificando como raça e parte responsável na relaçăo preconceituosa, é a sua representaçăo como um ser superior, portanto, modelo de aparência e de condiçâo humana, e, para o negro, a sua inferioridade racial, social e moral.

Năo se trata, portanto, da invisibilidade da cor, mas da intensa visibilidade da cor e de outros traços fenotípicos aliados a estereótipos sociais e morais, para uns, e a neutralidade racial, para outros. As consequências dessa visibilidade para os negros săo bem conhecidas, mas a da neutralidade do branco é dada como 'natural', já que é ele o modelo paradigmático de aparência e de condiçăo humana. (PIZA, 2014, p. 72)

Desse modo, o processo de construçâo da branquitude envolve aspectos como: vantagem, e privilégio racial năo associados à raça, o silêncio sobre sua racialidade e exposiçấo da racialidade do outro, poder real e simbólico de apelo ideológico, posiçăo de superioridade cotidianamente confirmada, evidência da raça do outro como diferença e hierarquia, preservaçăo da individualidade nas relaçóes cotidianas e năo reconhecimento como agente no processo discriminatório. E, essas consistências săo oferecidas pelo cotidiano, ou seja, nas relaçôes sociais racistas (PIZA, 2014).

Piza (2014) e Frankenberg (2004), estudiosa da branquitude norte-americana, argumentam que a invisibilidade, ou seja, a nâo-marcaçâo da branquitude, se caracteriza pela falta de percepçâo do próprio branco como ser racializado. Frankenberg (2004) sugere que é somente na medida em que se chega a determinados tipos de hegemonia da supremacia racial (poder, privilégio e dominaçáo branca) que a branquitude aproxima-se da invisibilidade, diluindo-se em uma falsa neutralidade, universalidade e normatividade. Todavia, quando se trata da política de açăo afirmativa, por exemplo, a branquitude é marcada e reconhecida pela maioria dos brancos para se mostrarem injustiçados em funçăo das vantagens obtidas pelos africano-americanos e, vez por outra, pelos latinos, nas chamadas cotas raciais.

Desse modo, nos últimos dez anos de seu trabalho sobre a branquitude, Ruth Frankenberg faz uma contribuiçâo para a visibilidade ou marcaçăo da branquitude, definindo oito pontos que indicam sua localizaçáo nas sociedades, que săo estruturadas na dominaçăo. Sầo eles:

1) A branquitude é um lugar de vantagem estrutural nas sociedades estruturadas na dominaçấo racial.

2) A branquitude é um "ponto de vista", um lugar a partir do qual nos vemos e vemos os outros e as ordens nacionais e globais.

3) A branquitude é um lócus de elaboraçăo de uma gama de práticas e identidades culturais, muitas vezes nâo marcadas e năo denominadas, ou denominadas como nacionais ou "normativas", em vez de especificamente raciais. 
4) A branquitude é comumente redenominada ou deslocada dentro das denominaçōes étnicas ou de classe.

5) Muitas vezes, a inclusăo na categoria "branco" é uma questăo controvertida e, em diferentes épocas e lugares, alguns tipos de branquitude sâo marcadores de fronteira da própria categoria.

6) Como lugar de privilégio, a branquitude náo é absoluta, mas atravessada por uma gama de outros eixos de privilégio ou subordinaçáo relativos; estes náo apagam nem tornam irrelevante o privilégio racial, mas o modulam ou modificam.

7) A branquitude é produto da história e é uma categoria relacional. Como outras localizaçóes raciais, nâo tem significado intrínseco, mas apenas significados socialmente construídos. Nessas condiçôes, os significados da branquitude têm camadas complexas e variam localmente e entre os locais; além disso, seus significados podem parecer simultaneamente maleáveis e inflexíveis.

8) O caráter relacional e socialmente construído da branquitude nâo significa, convém enfatizar, que esse e outros lugares raciais sejam irreais em seus efeitos materiais e discursivos. (FRANKENBERG, 2004, p. 312-313)

Lia Vainer Schucman, em pesquisa realizada para compreender de que forma a ideia de branquitude é apropriada e construída pelos sujeitos brancos da cidade de Sâo Paulo, também considera que, de fato, a branquitude é construída socialmente como lugar de privilégios materiais e simbólicos em que sujeitos considerados brancos transitam soberanos, em sociedades estruturadas pelo racismo, demarcando fronteiras hierarquizadas entre brancos e outras construçôes racializadas.

A branquitude é entendida como uma construçăo sócio-histórica produzida pela ideia falaciosa de superioridade racial branca, e que resulta, nas sociedades estruturadas pelo racismo, em uma posiçăo em que os sujeitos identificados como brancos adquirem privilégios simbólicos e materiais em relaçăo aos năo brancos. (SCHUCMAN, 2012, p. 07)

E, ainda, afirma a existência de marcadores espaciais simbolizados como bairros, ambientes e lugares considerados como "lugar de branco". "Há, por assim dizer, padrôes de diferenciaçăo social e de separaçăo, que variam na cidade e estruturam a vida pública e o relacionamento dos grupos raciais no espaço social" (SCHUCMAN, 2012, p. 108).

A invisibilidade também constitui a branquitude. Contudo, a invisibilidade nâo significa que a identidade racial branca seja invisível, mas que ela é revelada ou encoberta conforme os interesses em disputa (FRANKENBERG, 2004; SCHUCMAN, 2012; PIZA, 2014), como por exemplo, quando se fala na política de reserva de vagas para negros, os brancos veem a sua branquitude para argumentar que as cotas oferecem privilégio aos negros e os excluem porque "o problema do Brasil e da desigualdade é um problema de classe social que pode atingir a todos, e aí o discurso do mérito de que todos somos iguais reaparece" (SCHUCMAN, 2012, p. 77).

Observa ainda que, na construçáo social e diária da branquitude, as características raciais inscritas sobre o corpo, marcam o sujeito, ou seja, aqueles classificados socialmente como brancos adquirem significados positivos associados à inteligência, beleza, educaçăo, progresso, moralidade e poder, que acarretam o privilégio 
simbólico da superioridade racial. A consequência dessa ideologia racista é a crença de que a superioridade moral, intelectual e estética construída pelo racismo biológico do século XIX ainda continua sendo um aspecto da branquitude no Brasil (SCHUCMAN, 2012).

O corpo externa a cor, que é o sinal exterior mais visível da raça para os negros, e, por isso, torna-se o critério através do qual săo oprimidos e submetidos ao preconceito de cor, enquanto aos brancos a cor assegura privilégio. O estudo de Schucman (2012) também demonstra essa relaçâo quando, ao comparar brancos pobres com negros pobres, percebe que os significados construídos em torno da pertença racial branca asseguram aos brancos, mesmo em situaçăo de pobreza, privilégios e vantagens em diversos setores sociais.

\title{
4. POR UMA PEDAGODIA CRÍTICA DA BRANQUITUDE
}

\author{
Superioridade? Inferioridade? \\ [...] Minha última prece: Ô meu corpo, faça sempre de mim um ser que \\ questiona. (FANON, 2008, p.191)
}

Silvério e Trinidad (2012), no trabalho: Há algo novo a se dizer sobre as relaçôes raciais no Brasil contemporâneo, apontam que na direçăo de uma educaçăo antirracista a Constituiçấo de 1988, a aprovaçấo da Lei 10.639, de 2003 que trata da obrigatoriedade do ensino da história e da cultura afro-brasileira e africana no âmbito de todo o currículo escolar e as diretrizes para a Educaçăo das Relaçōes Étnico-Raciais, resultam no reconhecimento da discriminaçáo racial e do racismo como constitutivos de nossa formaçăo social, que, por sua vez, contraria o mito da democracia racial. Assim, a educaçâo como prática social e histórica, vem adquirindo centralidade na luta pela inclusăo social e pelo resgate da contribuiçăo das culturas africanas e indígenas para a formaçăo social brasileira, principalmente na açăo cultural e política do movimento negro, que acredita no potencial da educaçấo formal para o fim das desigualdades educacionais e sociais geradas pelas práticas históricas de racismo e discriminação direcionados aos năo brancos.

Ademais, os autores ressaltam que o cenário político-acadêmico brasileiro tem feito re (apropriaçóes) do termo raça, rejeitando a ideologia cientificista e essencialista europeia, que durante o século XIX impregnou o pensamento social por meio da Biologia e da Antropologia Física, na qual a ideia de raça passou a ser entendida como parte de um sistema de classificaçáo usado para interpretar as diferenças visíveis - fenotípicas e socioculturais - da espécie humana e transformá-las em desigualdade social, e, que, portanto, legitimou o racismo. Assim, a (re) apropriaçăo do termo raça como uma categoria histórica e socialmente construída vem demonstrando o seu potencial no desvelamento da racializaçăo pretérita da sociedade brasileira. E, esse pensar é um dos pontos fundamentais para uma abordagem crítica sobre a branquitude.

É um pensar crítico e emancipatório voltado à humanizaçâo dos sujeitos. Nesse sentido, há que se destacar que apesar de Frantz Omar Fanon, na sua trajetória de intelectual anticolonial, năo ter desenvolvido uma teoria educacional, suas ideias 
inspiram uma educaçăo que, enquanto prática social e histórica, pretende desenvolver a desalienaçăo e a emancipaçăo humana. Para Fanon, a alienaçăo é a perda de si ou a capacidade de se autodeterminar como sujeito (FAUSTINO, 2015). A alienaçấo intelectual é uma criaçăo da sociedade burguesa que proíbe a descoberta, apodrece as mentes, fixa o ser em si, desumaniza, torna as pessoas oclusas, a-históricas, passivas e impedidas de pensar - de respirar - de se definir enquanto ser, de ser livre para descobrir, criar e recriar novas formas de existência. Fanon (2018) argumenta ainda, que quando uma pessoa toma posiçáo contra esse tipo de morte, ou contra qualquer tentativa de opressâo, é, em certo sentido, um revolucionário, um desalienado. "Serâo desalienados pretos e brancos que se recusaráo enclausurar-se na Torre substanciada do Passado. Por outro lado, para muitos outros pretos, a desalienaçâo nascerá da recusa em aceitar a atualidade como definitiva" (FANON, 2008, p.187).

Como se vê, Fanon (2008) argumenta que essa açăo, ou seja, essa tomada de posiçăo precisa ser realizada por todos os homens, ou seja, por toda a humanidade. É necessário que todas as pessoas se permitam questionar, descobrir, revelar, sentir e querer bem, onde quer que se encontrem, a fim de que a verdadeira comunicaçáo humana possa acontecer.

O preto năo é. Nâo mais do que o branco. Todos os dois têm de se afastar das vozes desumanas de seus ancestrais respectivos, a fim de que nasça uma autêntica comunicaçăo. Antes de se engajar na voz positiva, há a ser realizada uma tentativa de desalienaçăo em prol da liberdade. [...] É através de uma tentativa de retomada de si e despojamento, é pela tensăo permanente de sula liberdade que os homens podem criar as condiçôes de existência ideais em um mundo humano. (FANON, 2008, p.191)

A pedagogia libertadora de Paulo Freire, cujo pensamento recebe influências de Frantz Omar Fanon, tem o diálogo e a problematizaçăo como categorias norteadoras de uma educaçấo crítica e emancipatória voltada à humanizaçăo e libertaçâo autêntica dos sujeitos, e, portanto, ao desenvolvimento de um pensamento crítico, epistemologicamente curioso, capaz de compreender a realidade social, apreender - construir e reconstruir - e superar a ideologia da opressăo. Nessa concepçăo, o ato de conhecer năo se dá de forma automática e individual, mas de maneira contínua, rigorosa e na intercomunicaçăo e intersubjetividade. Os sujeitos dialógicos mutuamente se educam intermediados pelo mundo cognoscível. Assim, dialogam, problematizam, isto é, fazem uma análise crítica da realidade concreta, e constroem conhecimento, porque "náo há inteligibilidade que nâo seja comunicaçăo e intercomunicaçâo e que nâo se funde na dialogicidade" (FREIRE, 1999, p.42).

No pensamento político-pedagógico de Paulo Freire, a prática é dialógica, na qual, o diálogo é construçaâo teórica, é participaçāo, é democrático, é aberto ao reconhecimento da diferença, é recíproco, é indagador, é respeitoso, é libertador e favorece o pensamento crítico e problematizador como sendo a maneira de ultrapassar a mera compreensăo e a possibilidade de voltar às questôes do cotidiano com associaçấo dos saberes à realidade concreta, isto é, ao contexto social, histórico, político e cultural. O diálogo implica na práxis social comprometida com a açăo transformadora realizada pelos seres humanos, compreendidos como seres históricos e sociais, seres pensantes capazes de comparar, valorar, intervir, escolher, decidir, desvelar verdades e 
romper. “É nesse sentido também que a dialogicidade verdadeira, em que os sujeitos dialógicos apreendem e crescem na diferença, sobretudo no respeito a ela, é a forma radicalmente verdadeira de humanizar, de ser e estar no mundo" (FREIRE, 1999, p.67). Uma pedagogia comprometida com a humanizaçăo dos sujeitos.

Freire (1999), ressalta que uma prática dialógica nâo é uma pratica racista, năo é preconceituosa, e, por isso, tem o dever de desvelar, de fazer uma reflexăo crítica acerca do racismo como transgressor da natureza humana e inerente ao contexto histórico de dominaçâo econômica e social do colonizador branco; da superioridade da branquitude; sobre discursos como: "a ciência diz que o negro é geneticamente inferior ao branco"; sobre o significado do silencio opressor e todo tipo de preconceito e discriminaçăo. "Qualquer discriminaçâo é imoral e lutar contra ela é um dever por mais que se reconheça a força dos condicionamentos a enfrentar" (FREIRE, 1999, p.67). Assim, o paradigma da pedagogia crítica, progressista e libertadora freireana e suas categorias fundamentais como problematizaçăo e diálogo, visa o desenvolvimento da consciência crítica, de corpos conscientes, de seres humanos sociais e históricos inacabados criadores e recriadores de suas formas de existência, que apreendem criticamente a realidade social e se insirem na luta pela superaçâo das formas de opressáo existentes na sociedade contemporânea, a exemplo da luta antirracista. E, como bem diz Fanon (2018, p.186) "para um ser que adquiriu a consciência de si e de seu corpo, que chegou à dialética do sujeito e do objeto, o corpo năo é mais a causa da estrutura da consciência, tornou-se objeto da consciência".

Contribuindo com essa ideia, Henry A. Giroux, teórico da sociologia da educaçăo e influenciado pela pedagogia crítica de Paulo Freire, reconhece a importância das reflexôes feitas por acadêmicos críticos que ajudaram a expandir o debate da ideia de raça e poder, no sentido de incluir a branquitude como uma construçâo social, histórica, cultural e política, embora esse conhecimento náo tenha revelado a capacidade de desconstruçăo da branquitude na esfera pública. Para Giroux (1999), é necessário reconhecer o potencial crítico da branquitude por meio da teorizaçăo e discussâo crítica entre estudantes negros e brancos sobre a representaçăo de si e do outro e da posiçâo da branquitude como o referente dominante. Nesse processo, para o autor, os estudantes brancos podem decidir seu modo de agir e assumir seu lugar legítimo na luta pela mudança social e por uma sociedade antirracista.

Nesse sentido, para o autor, a pedagogia da branquitude desconstrói criticamente a qualificaçáo do outro e da branquitude racial como parte de um discurso mais amplo de justiça racial. Assim, o espaço pedagógico precisa ler representaçôes contraditórias da branquitude como uma ideologia e um lugar de poder e privilégio. Desse modo, romper definiçóes singulares da branquitude fornece aos educadores críticos a oportunidade de construir modelos mais complexos para teorizar esse conceito utilizando-se de uma multiplicidade de relaçôes sociais, posiçōes teóricas e identificaçōes afetivas. Nesse contexto, a branquitude pode se tornar pedagógica por permitir que as tensóes nas relaçóes raciais sejam tratadas a partir de uma conceituaçăo nova. Assim sendo, a branquitude pode ser lida como uma representaçăo mutável e (re) construída com e por meio da diferença, pela qual os sujeitos e grupos sociais compreendem quem săo e definem seus modos de agir guiados por referentes éticos e políticos que se relacionam com as lutas, relaçōes e práticas democráticas. 


\section{CONSIDERAÇÕES FINAIS}

A branquitude é uma construçâo social de significados em que os sujeitos brancos se apropriam da categoria raça e do racismo na constituiçăo de suas subjetividades e ao se apropriarem acreditam que "ser branco" determina características morais, intelectuais e estéticas dos indivíduos que os diferenciam de outros e os asseguram, silenciosamente, a manutençâo de uma pretensa superioridade construída no contexto de dominaçáo econômica e social da modernidade/colonialidade, bem como, no racismo biológico do século XIX no Brasil.

Por consequência, a branquitude, como referente de humanidade universal, e, portanto, de representaçáo de superioridade, poder e privilégio racial, estabelece hierarquias sociais entre brancos, negros, indígenas e outras construçôes racializadas, sem que isso seja reconhecido como um privilégio e parte essencial na permanência das desigualdades raciais no Brasil. Desse modo, o que se entende por raça passa a ser critério de oportunidades e barreiras vividas pelos sujeitos considerados náo brancos por toda a sua vida.

Em razâo disso, na direçâo de uma educaçăo antirracista, este artigo argumenta por uma pedagogia crítica da branquitude no sentido de problematizá-la enquanto modelo universal de humanidade, por meio de uma prática dialógica em que os sujeitos e grupos sociais pensem criticamente sobre a representaçấo de si e do outro e (re) construam a branquitude como uma representaçăo năo fixa e guiada por referenciais que se associam com lutas, relaçōes e práticas democráticas e comprometidas com a humanizaçăo, emancipaçăo e libertaçăo autêntica dos sujeitos.

Assim, o potencial crítico da branquitude é reconhecido na medida em que passa a ser compreendida como uma representaçâo mutável e (re)construída com e por meio da diferença, a fim de revelar e desconstruir o processo continuado e silenciado de diferenciaçấo e hierarquizaçâo dos grupos sociais racialmente inferiorizados, além de confrontar os regimes racializados de representaçăo. Por fim, uma pedagogia crítica da branquitude ajuda a pensar que as diferenças precisam ser reinventadas a partir de um diálogo crítico das identidades marcadas, de maneira que os sujeitos brancos possam decidir seu modo de agir e assumir seu lugar legítimo na luta pela mudança social e por uma sociedade antirracista e democrática. 


\section{REFERÊNCIAS}

AZEVEDO, C. M. M. Onda negra, medo branco: o negro no imaginário das elites - século XIX. Rio de Janeiro: Paz e Terra, 1987.

BENTO, M. A. S. Branqueamento e branquitude no Brasil. In: CARONE, I.; BENTO, M. A. S. (Org.). Psicologia Social do Racismo: estudos sobre branquitude e branqueamento no Brasil. Petrópolis, RJ: Vozes, 2014, p. 25-58.

BENTO, Maria Aparecida Siva. Branquitude e poder: a questăo das cotas para negros. Simpósio Internacional do Adolescente. Săo Paulo, 2005. Disponível em: <http:// www.proceedings.scielo.br/scielo.php?script=sci_arttext\&pid=MSC0000000082 $005000100005 \& \operatorname{lng}=e n \& n r m=a b n>$. Acesso em: 12 de fev. 2020.

BERNARDINO-COSTA, J.; MALDONADO-TORRES, N.; GROSFOGUEL, R. (Org.) Decolonialidade e pensamento afrodiaspórico. Belo Horizonte: Autêntica, 2018.

CARONE, I. Breve histórico de uma pesquisa psicossocial sobre a questăo racial brasileira. In: CARONE, I.; BENTO, M. A. S. (Org.). Psicologia Social do Racismo: estudos sobre branquitude e branqueamento no Brasil. Petrópolis, RJ: Vozes, 2014. p. 13-23.

CARONE, I.; BENTO, M. A. S. (Org.). Psicologia Social do Racismo: estudos sobre branquitude e branqueamento no Brasil. Petrópolis, RJ: Vozes, 2014.

DÁVILA, Jerry. Diploma de brancura: política social e racial no Brasil (1917-1945). Trad. Claudia Sant'Ana Martins. Săo Paulo: Editora Unesp, 2006.

DU BOIS, W. E. B. As almas da gente negra. Rio de Janeiro: Lacerda, 1999.

FANON, Frantz. Os condenados da terra. Rio de Janeiro: Civilizaçăo brasileira, 1968.

FANON, Frantz. Pele negra, máscaras brancas. Salvador: EDUFBA, 2008.

FERES JÚNIOR, J.; A atualidade do pensamento de Guerreiro Ramos: branquidade e naçăo. Caderno CrH, Salvador, v. 28, n. 73, p. 111-125, 2015.

FRANKENBERG, Ruth. A miragem de uma branquidade năo-marcada. In: WARE, Vron (Org.). Branquidade: identidade branca e multiculturalismo. Rio de Janeiro: Garamond, 2004, p. 307-338.

FREIRE, P. Pedagogia da Autonomia: saberes necessários à prática educativa. Sáo Paulo: Paz e Terra, 1999.

GILROY, Paul. O Atlântico Negro. Modernidade e dupla consciência. Săo Paulo, Rio de Janeiro, 34/Universidade Cândido Mendes - Centro de Estudos Afro-Asiáticos, 2001.

GIROUX, Henry A. Por uma pedagogia e política da branquitude. Cadernos de pesquisa, n. 107, p. 97-132, 1999.

GROSFOGUEL, R. Para uma visăo decolonial da crise civilizatória e dos paradigmas da esquerda ocidentalizada. In: BERNARDINO-COSTA, J.; MALDONADO-TORRES, N.; GROSFOGUEL, R. (Org.) Decolonialidade e pensamento afrodiaspórico. Belo Horizonte: Autêntica, 2018. p. 55-77.

GUERREIRO RAMOS, A. Introduçāo Crítica à Sociologia Brasileira. Rio de Janeiro: Editora da UFRJ, 1995. 
HALL, S. Cultura e representaçăo. Rio de Janeiro: PUC-Rio, 2016.

MIGNOLO, Walter; ESCOBAR, Arturo (Eds.). Globalization and the Decolonial Option. London: Routledge, 2010.

MILANEZ, F.; SÁ, L.; KRENAK, A.; CRUZ, F. S. M.; RAMOS, E. U.; JESUS, G. dos S. de. Existência e diferença: o racismo contra os povos indígenas. Rev. Direito Práx. Rio de Janeiro, Vol. 10, n. 03, p. 2161-2181, 2019.

PIZA, E. Porta de vidro: entrada para a branquitude. In: CARONE, I.; BENTO, M. A. S. (Org.). Psicologia Social do Racismo: estudos sobre branquitude e branqueamento no Brasil. 6. ed. Petrópolis, RJ: Vozes, 2014. p. 59-90.

PIZA, E.; ROSEMBERG, F. Cor nos censos brasileiros. In: CARONE, I.; BENTO, M. A. S. (Org.). Psicologia Social do Racismo: estudos sobre branquitude e branqueamento no Brasil. 6. ed. Petrópolis, RJ: Vozes, 2014. p. 91-120.

SANTOS, J. R. dos. Culturas negras, civilizaçâo brasileira. Revista do Patrimônio Histórico e Artístico Nacional. Rio de Janeiro, IPHAN/MinC, 1997.

SCHUCMAN, L. V. Entre o "branco", o “encardido" e o "branquíssimo": raça, hierarquia e poder na construçấo da branquitude paulistana. 2012. 160 f. Tese (Doutorado em Psicologia Social ) - Programa de Pós-Graduaçâo em Psicologia Social. Universidade de Săo Paulo, Săo Paulo, 2012.

SILVÉRIO, V. R. Açăo afirmativa e o combate ao racismo institucional no Brasil. Cad. Pesquisa, n. 117, p. 219-46, 2002.

SILVÉRIO, V. R. Quem negro foi e quem negro é? Anotaçōes para uma sociologia política transnacional negra. In: BERNARDINO-COSTA, J.; MALDONADO-TORRES, N.; GROSFOGUEL, R. (Org.) Decolonialidade e pensamento afrodiaspórico. Belo Horizonte: Autêntica, 2018. p. 269-284.

SILVÉRIO, V. R.; TRINIDAD, C. T. Há algo novo a se dizer sobre as relaçôes raciais no Brasil contemporâneo? Edu. Soc., Campinas, v. 33, n. 120, p. 891-914, 2012.

SILVA, N. do V.; HASEMBALG, C. A. Relaçôes Raciais no Brasil Contemporâneo. Rio de Janeiro: Rio Fundo, 1992.

QUIJANO, A. Colonialidade do poder, Eurocentrismo e América Latina: perspectivas latino- americanas. Clacso, Buenos Aires, 2005. Disponível em: <http://bibliotecavirtual. clacso.org.ar/clacso/sur-sur/20100624103322/12_Quijano.pdf>. Acesso em: 12 de Jan. 2020. 